\title{
The Effect of Lexical Bundles on Iranian EFL Learners Linguistic Production Fluency
}

\author{
Nosrat Ranjbar ${ }^{1}$, Abdolreza Pazhakh $^{2} \&$ Bahman Gorjian $^{3}$ \\ ${ }^{1}$ M. A. in TEFL, Department of Language, Science and Research Branch, Islamic Azad University, Khuzestan, \\ Iran \\ ${ }^{2}$ Assistant Professor of Teaching, English Language Department, Dezfoul Branch, Islamic Azad University, \\ Dezfoul, Iran \\ ${ }^{3}$ Assistant professor in linguistics, English Language Department, Abadan Branch, Islamic Azad University, \\ Abadan, Iran \\ Correspondence: Nosrat Ranjbar, M.A. in TEFL, Department of Language, Science and Research Branch, Islamic \\ Azad University, Khuzestan, Iran. Tel: 98-641-626-0052. E-mail: pazhakh@gmail.com
}

Received: March 19, $2012 \quad$ Accepted: April 6, $2012 \quad$ Online Published: July 22, 2012

doi:10.5539/ies.v5n4p243 URL: http://dx.doi.org/10.5539/ies.v5n4p243

\begin{abstract}
The present study attempted to investigate the effects of lexical bundles on Iranian EFL learners' paragraph writing production fluency. To achieve this purpose, an English language proficiency test was administered to 120 language learners studying TEFL at Islamic Azad University of Dehloran. Ultimately, 90 language learners were selected and randomly divided into two groups of control and experimental groups, based on their proficiency testscores.Both experimental and control groups worked on the same text- book content. The experimental group subjects were instructed on the lexical bundles use extracted from True to Life text- book, while the control group received placebo treatment during the course. The treatment took a whole academic semester. The results of the post-test showed that lexical bundles teaching methodology proved effective and influential in developing Iranian EFL language learners' paragraph writing fluency. So, Developing English language skills, here writing skill in general and paragraph writing in particular, also, needs appropriate methods of which lexical bundles teaching methodology can be named.Since, lexical bundles use during instructional courses, help language learners have an automatic and easy recall of them in the process of paragraph writing, lexical bundles teaching methodology should be applied to having a better understanding of the text- books materials and to develop language skills. Therefore, the study suggests that content developers should include lexical bundles teaching methodology and their uses in the teaching and learning processes. The findings of this study gave empirical support to this view. Hence, this is pedagogically central in the domain of language teaching and learning and should be taken into account in the design and production of suitable instructional materials and in the methodology of classroom teaching and students learning behavior. To sum up, these findings can have a number of implications for material designers, language teachers, and students who are engaged in the teaching of English language as a foreign language.
\end{abstract}

Keywords: lexical bundles, fluency, linguistic production fluency

\section{Introduction}

Biber, Johansson, leech, Conrad, and Finegan (1999) developed a recent class of word collocation. They called them lexical bundles and defined them as recurrent expressions. To some linguists such as (Nattinger and Decarrico1992; Yorio, 1979) lexical bundles are referred to as prefabricated language units. Based on their findings, prefabricated language units are easily memorized and retrieved when the situation demands. It helps both speakers and listeners focus on the language structure of the discourse not just focus on the individual words.An important component of fluent linguistic production is mastering the multi-word expressions referred to as clusters, chunks or bundles. These are extended collocations which appear more frequently than expected by chance, helping to shape meanings in specific contexts and contributing to our sense of coherence in a text. Bundles have begun to attract considerable attention to corpus studies in EAP (Biber, Johansson, Leech, Conrad, and Finegan, 1999). 
Lexical bundles, coined by Biber, Johansson, Leech, Conrad, and Finegan (1999) are considered as a specific and relatively recent category of word combinations with a formulaic status (Biber and Barbieri, 2007). They defined lexical bundles as recurrent expressions, regardless of their idiomaticity, and their structural status. Frequency is the most salient and defining characteristic of bundles; in order for a word combination to count as a bundle, it must occur at least ten times in a corpus made of one million words with the additional requirement that this rate of occurrence be realized in at least five different texts to guard against idiosyncratic or repetitive uses (Biber, Johansson, Leech, Conrad, and Finegan, 1999).

Some corpus- based studies in spoken academic discourse and some investigations studied and proved some major features of lexical bundles and also developed structural and functional classifications of bundles. The following paragraphs report some of these researches and their results.

Lexical bundles have been classified functionally by Cortes (2001a) and Biber, Conrad, and Cortes (2003). The functions in their taxonomy refer to the meanings and purposes of the language, functions which contribute to providing texture or organizing the discourse according to situations or contexts. Taxonomy was designed by Biber, Johansson, S., Leech, G., Conrad, S., and Finegan (1999), using the most frequent bundles identified in conversation and academic prose. The four core categories in this taxonomy, used in the current study are: referential bundles, text organizers, stance bundles, and interactional bundles. These four categories could be tied to the linguistic functions described by Halliday (1971), in Webster, 2002). Halliday's (1971) idea of meta-function consists of the ideational function, the interpersonal function, and the textual function. Ideational function helps speaker or writer to enter the real world experience into the language. This function consists of one's internal experience of perception, cognition and consciousness. The second function deals with setting up relationship between the speaker and the listener and also expressing one's attitudes and comments using language. Halliday's last function was textual function. This function explains that how can a speaker or a writer make a unified and coherent text from a random list of written and spoken sentences. It describes the connection between the language and situation. It is through this function that a speaker or a writer can produce a text and then the reader or the listener can recognize it.

To some linguists (Nattinger, and Decarrico1992; Yorio 1979), lexical bundles are referred to as prefabricated language units. These prefabricated language units are easily memorized and retrieved when the situation demands. It helps both speakers and listeners focus on the language structure of the discourse not just focus on the individual words. This helps speakers speak fluently and facilitates communication. One insight about speaking fluency is that if EFL/ ESL students focus their attention on the selection of units of language and the production of the selected units, they can improve their speaking fluency (Gatbonton, and Segalowits 1988).

Unlike the traditional definition of fluency, as language mastery and native like performance, Brumfit (1984) describes it as natural language use. He defined fluency as the maximum efficient and active language operation and use at any level of proficiency, using the language system acquired by students. Brown (2003) gives some definitions for fluencyanddefined speaking fluency as automatic production of language units and focusing on meaning rather than on form. Writing fluency is, however, defined as the natural flow and organization of a written work.

Regarding the fact that in any speech event interlocutors have to initiate, maintain, and to finalize their speech to be termed a successful negotiation, the use of lexical bundles causes the matter of fluency chain of talk go on progressively and makes interlocutors get interested in continuation of the discussion. Besides this, the supra-segmental features of the speech enhance which, in turn, increase the attention concentration of audiences. Finally, all these matters have been resulted from the use of lexical bundles or chunks in the speech process. This, in turn, leads to an enhancement in understanding along with more satisfaction and fluency, respectively, both on the part of English as foreign language speakers and listeners. A great problem strikes any researcher concerning the reason why after learning and studying, Iranian EFL learners fail to face and tackle a conversation negotiatively with a foreigner who speaks English as a native speaker or as an ESL speaker and also their linguistic production fluency is not satisfactory. Even if they do their best, their fluency lags behind their intention, so their communication most commonly breaks down. Relying on this problem, the present researcher selects teaching lexical bundles or string of words in order to improve their level of proficiency and fluency in the process of linguistic production. In order to provide them with a proper technique to eliminate this issue, this research will be done around the effect of lexical bundles on Iranian EFL learners' fluency in linguistic production is designed.

Iranian English as foreign language learners have some problems in writing unified paragraphs. Or they may not know what methods they should use in order to improve their writing performance, in general, and paragraph 
writing in particular. To contribute English language learners' writing fluency, use of lexical bundles as an appropriate method is determined to be instructed to the sample under the study. Since, lexical bundles use during instructional courses, help language learners have an automatic and easy recall of them in the process of paragraph writing, lexical bundles teaching methodology should be applied to having a better understanding of the text- books materials and to develop language skills.

Hence, considering the role of lexical bundles in the development of language proficiency and fluency in linguistic production, the present researcher runs this experimental study to measure the impact of lexical bundles on Iranian EFL learners' linguistic production fluency. So,this research aims to study to measure the impact of lexical bundles on Iranian EFL learners' development of writing fluency.

\section{Literature Review}

Collocation was first introduced by Jepersen (1924). Later it was formally entered into the domain of linguistics by Firth (1957). Different linguists and scholars defined it differently. For example, Cruse (1986) defined collocation as sequences of words that co-occur and are transparent in meaning that is each lexical item in that sequence is a semantic constituent. Cruse pointed out that within a collocation the elements are mutually selective and also a kind of semantic cohesion exists between its elements.Before a sequence of words can be viewed as a collocation, a condition was set by Krishnamurthy (2004) and Lewis (2000). This condition was predictability of pattern. Based on this condition chance cannot guarantee that elements that occur with each other form a collocation, rather if one occurs, the occurrence of this word predicts the occurrence of the other words in that context than chance. So, pattern of predictability or mutual expectancy is a prerequisite for a set of words to be regarded as a collocation. And also, the habitual occurrence of the words in a collocation indicates that if one element of it is replaced by another similar word, this causes the collocation less acceptable (Graney, 2000; Shei, \&Pain 2000).

In addition, Biber and Barbieri (2007) studied the features of lexical bundles. In their investigation, they specified three major features for lexical bundles. The first feature of bundles deals with frequency of occurrence in written or spoken discourse. Their second feature is that they are usually incomplete phrases or clauses. Their third feature is that they are transparent in meaning not idiomatic. It means that it is easy to understand the meaning of bundles.

Also, Biber, Conrad, and Cortes (2004) investigated lexical bundles and explained that two points are important in considering a lexical bundle. They highlighted frequency and range as two main considerations for a phrase to be viewed as a lexical bundle. They defined frequency as how often a bundle happens frequently and also referred to range as using a phrase in a range of texts, at least five different texts.

\subsection{Lexical Bundles and Fluency Relationship}

Regarding the relationship between lexical bundles and linguistic production fluency, Pawley and Syder(1983), Nattinger and DeCarico (1992), Chambers (1998) and Wood (2001, 2004), lexical bundles and formulaic language units help second language learners to increase their speech speed by building sentences and increasing the length of their speech. These authors believed that if learners memorized a large amount of bundles and automatically retrieve them, they can gain a native like fluency and increase the length of the speech between pauses.

So, recurrent formulaic multiword patterns are highly used in natural languages both in spoken and written forms. The results of corpus linguistic research showed that these patterns are considerably used in natural language (Sinclair, 2004; Wray, 2002; Ellis, 2008). Based on these results, these formulae are more frequent in the spoken language rather than written discourse (Leech, 2000). Sinclair summarized the results of some corpus investigations and demonstrated that a large number of pre-constructed phrases are available to every language user. Although they may be analyzable, they constitute single segments. Moreover, language processing proved to be sensitive to collocation and formulaicity.

Additionally, some researchers focused on lexical bundles use in academic writing. They primarily noticed to the comparisons between writing performance of natives and non-natives English writers. Cortes (2002) compared native freshman compositions with academic prose. He found that novice writers used bundles functionally different from those bundles in published academic prose. Also, Cortes (2004) studied and compared lexical bundles in the writing of native students with those in academic journals. He found that those lexical bundles used in the corpus of published writing were rarely used by native students or even they used them in different ways. Moreover, Hyland (2008) worked on academic writing, concluding that there was disciplinary variation in lexical bundles use. Also, he compared lexical bundles use in postgraduate writing and published academic prose. He found that more formulaic expressions were used by postgraduate students than native academics in order to show their competence. 
Moreover, Ken Hyland (2008) believed that if readers and writers of any particular discourse participate regularly in that community, they are familiar with its lexical bundles. So, they can gain a natural language use and arrive at a qualified language use. But those readers and writers who newly come in to that community lack lexical bundles and this shortage of knowledge leads to lack of fluency.Considering the importance of the use of lexical bundles or chunks in the speech process, and in academic writing the main concern of the present study was to investigate whether or not there was a significant difference between the control and experimental group regarding the effect of teaching lexical bundles.

\section{Methodology}

\subsection{Participants}

From a junior population of 120 studying teaching English as a foreign language (TEFL) at Dehloran Islamic Azad University, 90 subjects within the age range of 20 to 25 were selected. They were all native Persian speakers. Moreover, 70 percent of the sample was females. The participants were randomly divided into two groups, that is, 45 students formed the control group and 45 of them considered as experimental group.

\subsection{Instrumentations \& Materials}

Two main instruments were used in this study. Initially, the subjects in both groups took an English language proficiency test. So, the first instrument was a pretest in order to find out participants linguistic abilities and also to make the sample homogeneous. The reliability of the test was .732 based on KR-21 method. It was used as an assessment tool for pretest and the posttest. The second one was a final test administered as post-test to check out the effects of the lexical bundles methodology on the linguistic production fluency of the students. The test was extracted from the True to life text-book. It was the main material of the study as the course text book for both control and experimental group.

\subsection{Procedure}

For the purpose of this study, both control and experimental groups were exposed to a pre test to observe their linguistic production abilities and their production of lexical bundles. During the treatment, the experimental group received instruction on lexical bundles in different contexts of conversation, role play, paragraph writing and discussion extracted from True To Life text- book for both groups. The control group received placebo treatment. In other words, the students of control group, unlike the experimental group received no instruction on lexical bundles and how to use them in different contexts. So, the control group worked on the same text-book content through conventional method of language teaching or Grammar Translation Method.The content was also the same for the two groups consisting of 5 units. After finishing the treatment, the two groups were exposed to posttest and then the results were analyzed. The research took a whole academic semester.

\section{Result and Discussion}

\subsection{Results}

This chapter dealt with calculating and analyzing the results of pretest and posttest mean scores obtained from experimental and control group. Before moving to the issue of the data analysis, the researcher prefers to have a quick look over the research variables. In the present study, the independent variable was lexical bundles teaching methodology and the dependent variable was paragraph writing fluency. The results of the study were significant enough for the two hypotheses at the 0.05 level of significance.

Table 4.1. Frequencies

\begin{tabular}{lllll}
\hline & Post-control & Post-exp. & Pre-control & Pre-exp. \\
\hline $\mathrm{N}$ & 45 & 45 & 45 & 45 \\
& & & & 7.3111 \\
Mean & 7.6222 & 17.9111 & 7.0860 & .92398 \\
Std. Deviation & 1.35745 & 1.22608 & .94062 & \\
\hline
\end{tabular}


Table 4.2. Paired sample test

\begin{tabular}{lllllll}
\hline & \multicolumn{5}{c}{ Paired differences } & \\
\cline { 2 - 5 } & mean & $\begin{array}{l}\text { Std. } \\
\text { deviation }\end{array}$ & $\begin{array}{l}\text { Std. } \\
\text { Error } \\
\text { mean }\end{array}$ & $\begin{array}{l}95 \% \\
\text { interval } \\
\text { difference }\end{array}$ & $\begin{array}{l}\text { confidence } \\
\text { of the }\end{array}$ & \\
& & & & lower & upper & \\
$\begin{array}{l}\text { Pre-post } \\
\text { exp. }\end{array}$ & -1060000 & 1.35361 & .20178 & -11.00667 & -10.19333 & -52.531 \\
\hline
\end{tabular}

Table 4.3. Inferential Statistics pertaining to the posttest

\begin{tabular}{|c|c|c|c|c|c|c|c|c|}
\hline \multirow[b]{3}{*}{$\begin{array}{l}\text { Equal } \\
\text { variances } \\
\text { assumed }\end{array}$} & \multicolumn{7}{|c|}{ Levene's Test for equality of variances } & \multirow{2}{*}{$\begin{array}{l}\text { T-Test for equality of } \\
\text { means } \\
95 \% \text { confidence interval } \\
\text { of the difference }\end{array}$} \\
\hline & $\mathrm{F}$ & Sig. & $\mathrm{t}$ & df & Sig.(2tailed) & $\begin{array}{l}\text { Mean } \\
\text { difference }\end{array}$ & $\begin{array}{l}\text { Std. Error } \\
\text { difference }\end{array}$ & \\
\hline & 2.153 & .146 & 5.640 & 88 & .000 & 8.84444 & 1.22608 & $\begin{array}{lr}\text { lower } & \text { upper } \\
-11.00667 & -10.19333\end{array}$ \\
\hline $\begin{array}{l}\text { Equal } \\
\text { variances } \\
\text { not } \\
\text { assumed }\end{array}$ & & & 5.640 & 45.212 & .000 & 8.84444 & 10.44771 & \\
\hline
\end{tabular}

In order to analyze the data related to the present research, this study made use of descriptive and inferential statistics. In this chapter, initially the statistical calculations and results are presented. Next, the results of the analysis will be discussed.This part deals with the statistical calculations of the pretest and posttest scores obtained from the two groups of experimental and control. The results of the statistics of frequency table (table 4.1) revealed that the mean scores of the experimental group and control group on the pretest were 7.3111 and 7.0860 , respectively. This showed that there was no significant difference between the two groups on the pretest. However, the results of the two groups' posttest revealed that the mean scores of experimental and control groupswere 17.9111 and 7.6222, respectively. The descriptive results of the posttest showed that there was difference between the posttest mean scores of the two groups. So, the posttest mean score of experimental group was very bigger than that of control group. But there were no enough documents to prove that this difference was significant. However, to find out if the difference between the experimental groups pretest and posttest mean scores was significant or not and to compare the mean scores, the results of the pretest and posttest were submitted to statistical t-test. Table 4.2 displayed the results of paired sample test pertaining to posttest. The results of the paired sample test showed that the t-test value was -52.531 and the significance level was .000. Armed with this information of very high t-test value and the significance value which was very bigger than its permissible value (sig $>0.05)$, the researcher can claim that the difference between the two groups mean scores was significant. This meant that the study accepted the first research hypothesis which stated that the instruction of lexical bundles influenced Iranian EFL learners' writing production fluency. Therefore, the lexical bundles instruction was influential and influenced the experimental groups writing production fluency.

To test the second research hypothesis of the study, the posttest mean scores of the control and experimental group were submitted to independent samples test. Table 4.3 present the results of independent sample test pertaining to the posttest. The results of the $t$-test revealed that $F$ value was 2.153 and the sig value was .146. Also, it revealed that the variances of the two groups were equal. Moreover, the t-test was 5.640 and the significance level was .000, which meant that the difference between the mean scores of control and experimental groups was significant. Therefore, the research accepted the second research hypothesis which pointed that there was significant difference between the experimental and control group mean scores on the posttest.So, the second null hypothesis was rejected. Thus, the difference between the two groups was significant. In other words, lexical bundles considered as an influential method and promoted the writing production fluency of experimental group. 


\subsection{Discussion}

This section discussed the results of the research by direct reference to the questions raised in the study. Question one: Does lexical bundles have any significant effect on Iranian EFL learners linguistic production fluency?

The present study showed that lexical bundles instruction could bring a significant change in the experimental group learners. Since experimental group learners received instruction on lexical bundles. They worked on lexical bundles in different contexts of role play, discussion, paragraph writing and conversation. During the treatment, experimental group utilized lexical bundles and wrote so many unified paragraphs about different topics. Then, they presented them in the class and discussed them. Also, they made use of lexical bundles and wrote conversation around the topics mentioned in their text-book. Finally they played the role of the provided conversations and text-book conversations, too. All these contexts and the received instruction helped learners promote their writing production fluency on the posttest. This, in turn, developed the experimental students' paragraph writing fluency. This development was due to the instruction and learning large amount of lexical bundles and automatically retrieved them in experimental group students' paragraph writing. Therefore, instructing Iranian EFL learners in lexical bundles and using them in different contexts promoted their linguistic production fluency. So, the research instruction was considered as an influential method.

As regards the participants in the control group, they did not receive any instruction on lexical bundles. They studied the same text-book (True to Life) through the conventional method of language teaching, grammar translation method. They received no instruction on lexical bundles. So, because they did not work on lexical bundles in different contexts, their performance on the posttest did not change much in comparison to their pretest mean score.Thus, the reason why the experimental and control group participants' performance on the post test was significantly different was due to instruction. Therefore, the results of the study revealed that the instruction of lexical bundles had a significant on Iranian EFL learners' writing production fluency.

Question Two: Is there any significant difference between experimental and control group mean scores on the posttest?

As it is discussed in the previous section of the current chapter, the results of the inferential statistics related to the second hypothesis revealed that the experimental and control group performed significantly different on the posttest. That is to say, the experimental group participants who received instruction on lexical bundles did much better than the control group students who did not receive instruction. This stated that there was a significant difference between the mean scores of experimental and control groups. In other words, this difference was due to the improvement of experimental group learners' writing production fluency. This improvement, in turn, was merely due to the instruction. Also, as regards the participants in the control group, they did not do well on the posttest in comparison to the experimental group participants. So, they did not show any improvement in their writing production fluency. This lack of improvement was due to the fact that they did not receive instruction on lexical bundles. They just received placebo instruction and did not work on bundles in different contexts. So, it was revealed through the results of the inferential statistics that control group participants did not show any improvement on the posttest. Thus, the difference between the two groups' mean scores on the posttest proved to be significant as the result of lexical bundles instruction. IN other words, there was a significant difference between the experimental and the control groupwriting production fluency.

As revealed in the present study, Iranian EFL learners majoring in TEFL received instruction on lexical bundles and showed a striking progress at the end of the treatment on the posttest. So, it is proved that the instruction was influential lexical bundles caused a significant promotion on Iranian EFL learners participated in this study. Finally, the researcher came to this conclusion from the current section that lexical bundles had a significant effect on Iranian EFL learners' writing production fluency. Moreover, there was a significant difference between the experimental and control group writing production fluency. Also, all these improvement and difference was due to the instruction of lexical bundles.

\section{Conclusion}

The present study sought to find out how learners' writing fluency is affected by lexical bundles teaching methodology. Investigating the effect of the lexical bundles use on the Iranian students' paragraph writing production fluency, 90 college students majoring in teaching English as a foreign language, were assigned to the experimental and the control group. The experimental group participants were exposed to teaching lexical bundles and the control groups did not receive any instruction in lexical bundles. They taught the same content through conventional method of grammar translation. The instruction lasted for a whole academic semester. During this time, the researcher employed lexical bundles teaching and taught the subjects in the experimental group how to use them in their different types of contexts. The participants in the control group, on the other hand, did not 
receive any instruction on the use of lexical bundles in their paragraph writing production fluency. After the posttest, the study results indicated that lexical bundles instruction affected the experimental group students' paragraph writing fluency. Also, the instruction of lexical bundles caused a significant difference between the experimental and control group writing performance on the posttest. That is, writing production fluency of the experimental group who had made use of lexical bundles surpassed that of the control group participants.

Based on the inferential statistics done, it can be concluded that lexical bundles use had a significant relationship with writing fluency. Also, there was a significant difference between the experimental and control group writing performance on the post- test. Therefore, content developers should include lexical bundles teaching methodology and their uses in the teaching and learning processes. The findings of this study gave empirical support to this view. Hence, this is pedagogically central in the domain of language teaching and learning and should be taken into account in the design and production of suitable instructional materials and in the methodology of classroom teaching and students learning behavior. To sum up, these findings can have a number of implications for material designers, language teachers, and students who are engaged in the teaching of English language as a foreign language.

As the study was conducted in the Islamic Azad University of Dehloran, more research is needed in similar situations and in state universities to support the findings and to find out more about the impacts of lexical bundles teaching methodology on university students' writing fluency. As the study was conducted to study the impacts of lexical bundles use on students' writing fluency, it might be interesting if it could investigate the effect of lexical bundles on writing along with any other skills on the same sample population at the same time. Thus, while the current investigation has some limitations, the results of this study provide direction for further research when taking the lexical bundles methodology and writing fluency into considerations.

Another suggestion for further research is to consider whether the improvement of the experimental group students was due to the independent variable of the study, lexical bundles teaching methodology or was due to more paragraph writing practice. So, further research is needed to be done to clarify this point and to find out the mechanisms that link writing fluency with lexical bundles use. So, more investigations may be necessary to do in order to convey the association of lexical bundles use with better understanding, and comprehension of the materials, writing fluency or the other language skills development of university students.

Still, researches can investigate the effect of bundles in spoken discourse, unlike the present researcher who has done it in the writing discourse. Also, they can investigate the frequency of bundles in any particular field in comparison to other fields of study or study the different categories of bundles such as functional classifications, stance, referential, and discourse organizers in at least two registers, unlike the present researcher who worked just in the domain of classroom teaching register. So, further studies may be required to engage the language methodologies and language teachers as the other pedagogical factors in the instruction and use of lexical bundles and their impact on the writing production fluency or even other language skills or sub-skills. Since this study was conducted on TEFL majors at university, some investigators have chance to consider the effect of lexical bundles on promoting the writing production fluency at secondary education at EFL contexts.

Finally a variety of study techniques and methods are available to syllabus designers, teachers, and students, but the current research focused only on the impact of lexical bundles teaching methodology on the students' writing fluency.

\section{References}

Biber, D., \& Barbieri, F. (2007). Lexical bundles in university spoken and written Registers. In: Neely, E. \& Cortes, V. A little bit about, analyzing and teaching lexical bundles in academic lectures. Georgia State University, 20-21.

Biber, D., Conrad, S., \& Cortes, V. (2003). Lexical bundles in speech and writing. In: Cortes, V. Lexical bundles in published and student disciplinary writing: Examples from history and biology. Iowa State University, Department of English203, Ross Hall, Ames IA 50014, USA, 399-400, 404, 408.

Biber, D., Conrad, S., \& Cortes, V. (2004). 'If you look at . . . . Lexical Bundles in University Teaching and Textbooks'. Applied Linguistics, 25(3), 374-378.

Biber, D., Johansson, S., Leech, G., Conrad, S., \& Finegan, E. (1999). Longman grammar of spoken and written English. In: Cortes, V. Lexical bundles in published and student disciplinarywriting: Examples from history and biology. Department of English, Iowa State University, 203 Ross Hall, Ames, IA 50014, USA, 399-411. 
Brown, J. (2003). Promoting Fluency in EFL classrooms. In: Al Sibai, D. Fluency ORAL FLUENCY: Promoting oral fluency of second language learners.literature Review. King Saud University: In partial fulfillment of the requirements for Educational Linguistics Department of English. Dr. DoganBulut. December 18, 2004, 4, 15.

Brumfit. C. J. (1984). Communicative Methodology in Language Teaching: The Roles of Fluency and Accuracy. In: Chambers, F. what do we mean by Fluency. University of Southampton, School of Modern Languages, Faculty of Arts, Avenue Campus. Southampton, SO17 LBF, UK, 536.

Chambers, F. (1997). What do we mean by fluency. Francine Chambers. University of Southampton, School of Modern Languages, Faculty of Arts, Avenue Campus. Southampton, SO17 LBF, UK, 25(4), 535-544.

Cortes, V. (2001a). Lexical bundles in published and student disciplinary writing: Examples from history and biology. V. Cortes. Iowa State University, Department of English, 203 Ross Hall, Ames, IA 50014, USA, 400 .

Cortes, V. (2002). Lexical bundles in freshman composition. In: Chen, Y. H., \& Baker, P. Lexical bundles in L1 and L2 academic writing. Lancaster University, June 2010, 14(2), 30-31.

Cortes, V. (2004). Lexical bundles in published and student disciplinary writing: Examples from history and biology. English for Specific Purposes, 23, 397-423. http://dx.doi.org/10.1016/j.esp.2003.12.001

Cruse, D. A. (1986). Lexical semantics. In: Sadeghi, K. Collocational differences between L1 and L2: Implications for EFL Learners and Teachers, 102.

Ellis, N. C. (2008). Optimizing the input.In: Simpson-Vlach, R., and Ellis, N. C. An Academic Formulas List: New Methods in Phraseology Research University of Michigan: rsimplach@gmail.com ncellis@umich.edu. To appear in Applied Linguistics, 2010 Accepted June 22, 2009 Prepublication draft. 4-5, 14-28; 4- 5.

Firth, J.R. (1957). Papers on Linguistics. In: Strunkyt, G., and Jurkūnait, E.Written Academic Discourse.Lexical bundles in Humanities and Natural Sciences. Thesis submitted in partial fulfillment of requirements for the degree of BA in English Philology Supervisor: DrAugustina Stungien.2008. Vilnius: University Faculty of Philology, Department of English Philology, 5.

Gatbonton, E., \& N. Segalowitz. (1988). In: Wood, D. Effects of focused instruction of formulaic sequences on fluent expression in second language narratives: A case study. Carleton University, 44.

Graney, J.M. (2000). Review of the article teaching collocation: Further developments in the lexicalapproach.In: Sadeghi, K. Collocational Differences between L1 and L2: Implications for EFL Learners and Teachers, 102-103.

Halliday M. A. K. (1971). In: Cortes, V. Lexical bundles in published and student disciplinary writing: Examples from history and biology. Iowa State University, Department of English, 203 Ross Hall, Ames, IA 50014, USA, 401, 404.

Hyland, K. (2008a). Academic clusters: Text patterning in published and postgraduate writing. In: Chen, Y. H., \& Baker, P. Lexical bundles in L1 and L2 academic writing. Lancaster University, June 2010, Volume 14, (2), 31-34, 43.

Jespersen, O. (1924). The philosophy of grammar. In: Cortes, V. Lexical bundles in published and student disciplinary writing: Examples from history and biology. Iowa State University, Department of English, 203 Ross Hall, Ames, IA 50014, USA, 398.

Krishnamurthy, R. (2004). English collocation studies: The OSTI report. In: Sadeghi, K. Collocational differences between L1 and L2: Implications for EFL Learners and Teachers, 103.

Leech, L. (2000). Grammars of spoken English: New outcomes of corpus-orientedresearch.In: Ellis, N. C. Formulaic Language in Native and Second Language Speakers: Psycholinguistics, Corpus Linguistics, and TESOL. University of Michigan Ann Arbor, Michigan, United States RITA SIMPSON-VLACH San José State University San José, California, United States CARSON MAYNARD University of Michigan Ann Arbor, Michigan, United States.376.

Lewis, M. (2000). Teaching collocation: Further developments in the lexical approach. InSadeghi, K. Collocational differences between L1 and L2, Implications for EFL Learners and Teachers, 103.

Nattinger, J. R., \& J. S. DeCarrico. (1992). Lexical phrases for the comprehension of academic lectures. In: Cortes, V. Lexical bundles in published and student disciplinary writing: Examples from history and biology. Iowa State University, Department of English, 203 Ross Hall, Ames, IA 50014, USA, 399. 
Pawley, A., \& Syder, F. H. (1983). Two puzzles for linguistic theory native like selection and native-like fluency. In Cortes, V. Lexical bundles in published and student disciplinary writing: Examples from history and biology. Iowa State University, Department of English 203 Ross Hall, Ames, IA 50014, USA, 398-399.

Shei, C., \& Pain, H. (2000). An ESL writer's collocational aid. In: Sadeghi, K. Collocational differences between L1 and L2: Implications for EFL Learners and Teachers, 101,103.

Sinclair, J. (2004). Trust the text: Language, corpus and discourse. In: Simpson-Vlach, R and Ellis, N. C.An Academic Formulas List: New Methods in Phraseology Research. University of Michigan rsimplach@gmail.com ncellis@umich.edu.To appear in Applied Linguistics, 2010 Accepted June 22, 2009 Prepublication draft. 4.

Webster, J. (Ed.). (2002). Linguistic studies of text and discourse.In: Cortes, V. Lexical bundles in published and student disciplinary writing: Examples from history and biology. Department of English, Iowa State University, 203 Ross Hall, Ames, IA 50014, USA, 401.

Wood, D. (2001, June, 2004). In Search of Fluency: What Is It and How Can We Teach It? [Electronic version]. In: Al Sibai, D. Fluency: Oral Fluency: Promoting oral fluency of second language learners, literature review. King Saud University: In partial fulfillment of the requirements for Educational Linguistics, Department of English I. Dr. DoganBulut, December 18, 2004. 2, 4, 15-18, 22-24.

Wray, A. (2002). Formulaic language and the lexicon.In: Ellis, N. C. Formulaic Language in Native and Second Language Speakers: Psycholinguistics, Corpus Linguistics, and TESOL. University of Michigan Ann Arbor, Michigan, United States RITA SIMPSON-VLACH San José State University San José, California, United States CARSON MAYNARD University of Michigan Ann Arbor, Michigan, United States.375, 377.

Yorio, C. (1979). On TESOL'79'.In: Strunkyt, G. \&Jurkūnait, E. Lexical bundles in Humanities and Natural Sciences. Vilnius: University Faculty of Philology Department of English Philology. 5. 